\title{
Transatlantica
}

Revue d'études américaines. American Studies Journal

\section{The Power of Parody: Went With the Wind (1976), a} Film Classic Revisited by The Carol Burnett Show (CBS, 1967-1978)

\section{Taïna Tuhkunen}

\section{(2) OpenEdition Journals}

Electronic version

URL: https://journals.openedition.org/transatlantica/14233

DOI: 10.4000/transatlantica.14233

ISSN: $1765-2766$

Publisher

Association française d'Etudes Américaines (AFEA)

Electronic reference

Taiina Tuhkunen, "The Power of Parody: Went With the Wind (1976), a Film Classic Revisited by The Carol Burnett Show (CBS, 1967-1978)", Transatlantica [Online], 1 | 2019, Online since 01 July 2020, connection on 02 February 2023. URL: http://journals.openedition.org/transatlantica/14233; DOI: https://doi.org/10.4000/transatlantica.14233

This text was automatically generated on 2 February 2023.

\section{c.) (i) $(9$}

Creative Commons - Attribution-NonCommercial-NoDerivatives 4.0 International - CC BY-NC-ND 4.0 https://creativecommons.org/licenses/by-nc-nd/4.0/ 


\title{
The Power of Parody: Went With the Wind (1976), a Film Classic Revisited by The Carol Burnett Show (CBS, 1967-1978)
}

\author{
Taïna Tuhkunen
}

The greater the work of literature, the easier the parody.

Ernest Hemingway

Parody is one of the major forms of modern selfreflexivity; it is a form of inter-art discourse.

Linda Hutcheon

1 Writers and film makers are known to have used a wide range of approaches and techniques to deal with well-known works in order to comment or re-represent them in oblique ways, sometimes in a purposely ludicrous light. One such technique is parody. While some such reviewers use more solemn tones to persuade their readers and spectators to accept new views on the existing, often quite eminent oeuvres, others prefer humor to engage us in a process of rereading, which may prove at once hysterical and intensely critical.

2 This is the case in the revisionary adaptation of the great Hollywood classic, Gone With the Wind (Victor Fleming, 1939), reworked into a TV parody by the award-winning variety series The Carol Burnett Show (1967-1978). Despite its condensed form (a 4-hour feature film truncated into a 19-minute-TV show), Went With the Wind ${ }^{1}$ managed to deconstruct the Southern "master narrative" by bringing to the fore some of the aesthetic, ideological and thematic features that underlie the insufferably supremacist yet pivotal and resistant cultural icon known as the "Southern Belle."2 


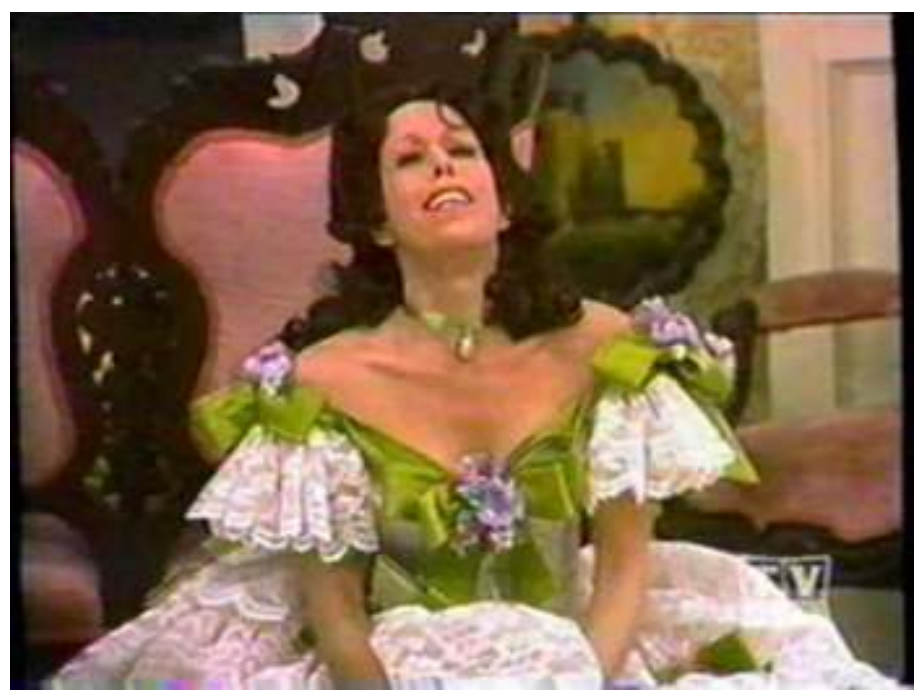

Starlet (Carol Burnett), the mistress of Terra. (Went With the Wind 06:43)

3 When discussing Went With the Wind and Carol Burnett's reconstructed, deliberately unladylike Southern Lady, one should keep in mind that a week before its transmission on CBS in 1976-roughly four decades after Gone With the Wind's carefully orchestrated and segregated ${ }^{3}$ premiere in Atlanta-the film adaptation of Margaret Mitchell's novel had been aired for the first time on national television, drawing millions of Americans in front of their TV sets across the country. But while thus warmed up for the Hollywood blockbuster that purportedly took the world by storm on the eve of the outbreak of the Second World War, people seemed ready for changing winds and for other types of tears than the ones classic Hollywood tearjerkers were meant to elicit.

4 For this was the 1970s, an era of heightened political and cultural awareness. In the wake of the mostly pacifist yet stormy 1960s' counter-culture movement, second-wave feminism and the emergence of feminist film theory, Hollywood melodramas and other so-called "women's films" were re-examined through a more critical lens. Instead of creating yet another sentimental and static topos of a supposedly "lost" social, racial as well as gendered harmony, the mythic "Southland" that had supposedly "gone with the wind" was now brought under pathos-free, overtly parodic scrutiny.

In 1976, few American TV spectators had read Marjorie Rosen's Popcorn Venus: Women, Movies, \& the American Dream, published in 1973, or knew about Molly Haskell's 1974 From Reverence to Rape: The Treatment of Women in the Movies, two early attempts to theorize cinema from a gendered standpoint. Even fewer viewers of The Carol Burnett Show were familiar with the British theorist Laura Mulvey's concept of "the male gaze" developed in her seminal 1975 essay "Visual Pleasure and Narrative Cinema" where she argued that the male-centric Hollywood system provided "narrative pleasure" primarily for men, reducing women to passive objects destined to help negotiate male anxieties. At the same time, feminist trends were already in the air, as radically new atmospheric elements were gaining momentum to push film scenarios towards more dynamic and empowering representations of women in order to endow them with more agency and depth. For although Vivienne Leigh's flamboyant Scarlett O'Hara had already outshined the classically gentle and docile "truly Southern Lady" emblematized by Melanie Wilkes (Olivia de Havilland) in Gone With the Wind, there was still plenty of rewriting to be done to help Scarlett break away from her final, punitive exile to Tara. 
Within its necessarily limited framework, this article wishes to explore the main melodramatic and linguistic features foregrounded in Went With the Wind at an age when "television began to take on the role of mass media parodist" (Harries 20). Instead of watering down the exceedingly romantic Southern melodrama, largely based on historically false facts, Carol Burnett's sketch generates further exaggerations and misrepresentations, tackling the cult text through misreadings and mockery which may be read as a double-edged homage to the subtext. We shall argue that despite the fact that The Carol Burnett Show evades race issues, the way it demystifies and takes down this celebrated cultural monument nevertheless sheds light on how Gone With the Wind also works as a versatile subtext, paving the way for later, more openly critical reassessments of the famous cultural construction rooted in a racist ideology and imagery.

7 As underlined by the show's very title, Burnett's Went With the Wind skit cannot be separated from playful punning which, together with early $20^{\text {th }}$-century dramatization techniques, allows the film to continue its provocative dialogue with one of the most controversial masterpieces of American literature and cinema through deliberate exaggeration, derision and distortion. Let us add that this article was finished before the oubreak of "the latest chapter in the tortured saga of America's relationship with Gone With the Wind" (Harris), after the removal of the film from the HBO Max streaming library, following John Ridley's article "Op-Ed: Hey, HBO, 'Gone With the Wind'romanticizes the horrors of slavery. Take it off your platform for now." Published in June 2020, in the aftermath of George Floyd's death at the hands of the Minneapolis police on May 25, 2020, Ridley's intervention urged to "take the movie down" temporarily from the streaming platform due to the way it "glorifies the antebellum South" and "pauses only to perpetuate some of the most painful stereotypes of people of color."

8 The present article cannot but agree with John Ridley, the Academy Award-winning screenwriter of 12 Years a Slave (Steve McQueen, 2013), who recalls that Gone With the Wind deliberately ignores the horrors of slavery by sentimentalizing a "history that never was." Just as firmly, I share Ridley's belief that censorship is not the solution, and that Gone With the Wind should not be relegated to film archives. Instead, as I will argue, it ought to be carefully examined through the contexts where it has reemerged as a literary, filmic, as well as ideological or counter-cultural intertext. For, while Gone With the Wind certainly needs to be contextualized and rediscussed, one should not overlook how-well before Tarantino's Django Unchained (2012) and Spike Lee's BlacKkKlansman (2018)-American popular culture challenged this debatable masterpiece using humor and parody as far-reaching tools when recomposing the scarlet-red herring, the colorful fantasy figure at the heart of the 1939 Technicolor drama which strives to lead us into an imaginary world where racism does not exist.

\section{Beneath and Beyond Carol Burnett's Went With The Wind}

Brashly : My money's gone.

Starlet : Gone? Gone where?

Brashly: It went with the wind. 
Carol Burnett's "mini version"4 is not the only parody of the 1939 blockbuster adaptation based on Margaret Mitchell's legendary 1936 bestseller. The novel's characters, themes and scenes have been revisited and retold in countless plays, sketches, songs and cartoons ${ }^{5}$; not to mention the miscellaneous gags, puns and jokes which, through their ironies, innuendos, and more or less witty misreadings, continue to bear witness to Scarlett O'Hara's Southern resilience and gumption loved and/or hated by millions of readers and spectators across the globe.

The mixed feelings triggered in more recent decades by Mitchell's narrative have sprouted a variety of offshoots. One of them is Beverly West and Nancy Peske's 1995 Frankly, Scarlett, I Do Give a Damn! A Parody: Classic Romances Retold!, ${ }^{6}$ a sketchy text that revises Mitchell's always more than a "romance novel" (Regis 50) by giving it a recognizably contemporary flavor. Remarkably enough, after claiming that he does give a damn, Rhett Butler suddenly evolves towards a drastically different political correctness:

"Let's go to your place," said Rhett, knowing that Tara was a touchstone for [Scarlett]. "I'll cook you a nice dinner, I'll lay a fire, and, with your consent, we can make passionate love, during which I will be as concerned with your pleasure as my own. Then, while you nap, I will wash the dishes and prepare a light, healthy snack to restore our expended energy." (West and Peske 4)

And as if doing the cooking and the washing-up, taking into consideration his spouse's consent, and including a post-coitus nap were not enough, the revamped, genderconscious Mr. Butler-known for the notorious domestic rape scene where the inebriated Brett picks Scarlett up and carries her rashly up the red-carpeted stairs to their bedroom-proposes a final twist by ending the story with the following words: “Just don't let the uncertainty of our future as citizens of a post-Reconstruction Southern society muddy your enjoyment of the moment. After all, tomorrow is another day." (West and Peske 5)

11 Among other Gone With the Wind-generated comic remakes and humorous recreations that look beyond stereotypes, we find, less unexpectedly, the animated sitcom The Simpsons and its twists to the already somewhat stale Southern story, despite the use of blazing Technicolor. After Scarlett's de-infatuation and tardy realization that her stubborn struggle to gain Ashley Wilkes's love was but a hazy dream or a blinding fantasy, she dashes down the magnificent staircase of the Butlers' Atlanta mansion, only to realize that-fed up with her Southern Bellish whims-Rhett has decided to walk out on her. This is when Rhett, already at the front door, turns around, and against all odds blurts out an incongruous wish to tie the knot again with Scarlett in words which squeeze out the juice from the original punchline: "Frankly, my darling, I love you. Let's remarry!" 


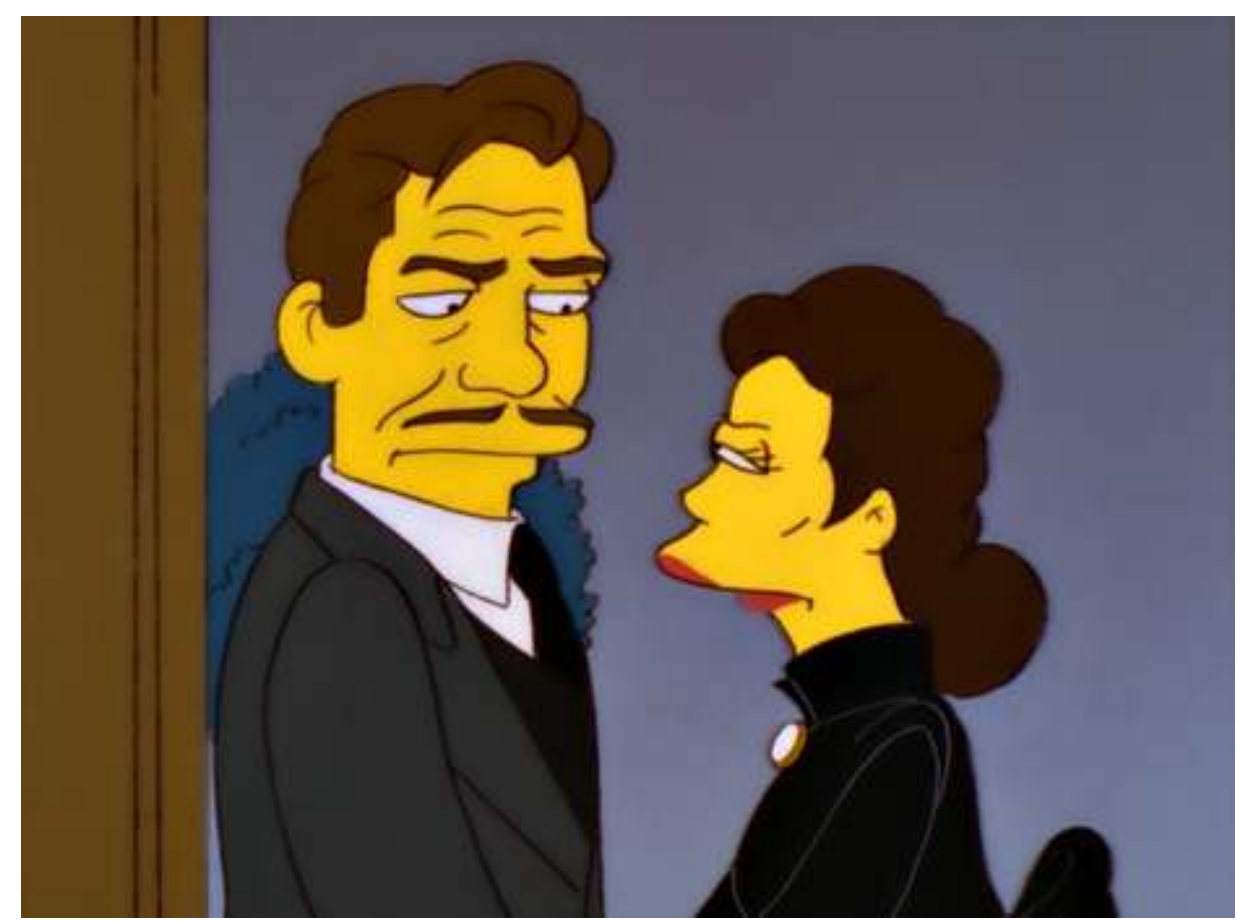

"Frankly, my darling, I love you. Let's remarry!" The Simpsons, Season 10, episode 223 (S10Ep20)7

12 Leaving out the crucial "I don't give a damn"-expletive from the most famous movie quote in American film history, The Simpsons recalls how parodic disruptions do not simply rely on overstatement, but on understatement. Whichever the means used to create hyperbolic or, on the contrary, more toned-down connections with the subtextor what Linda Hutcheon calls the "background text" - the message is clear enough: the Southern metanarrative about the "Lost Cause" is to go on. Not only to spice up the text with a touch of political correctness, but to put to test the capacity of the parodic text to pursue an intertextual and intergenerational dialogue with the parodied text by evoking other, present-day losses and gains. 


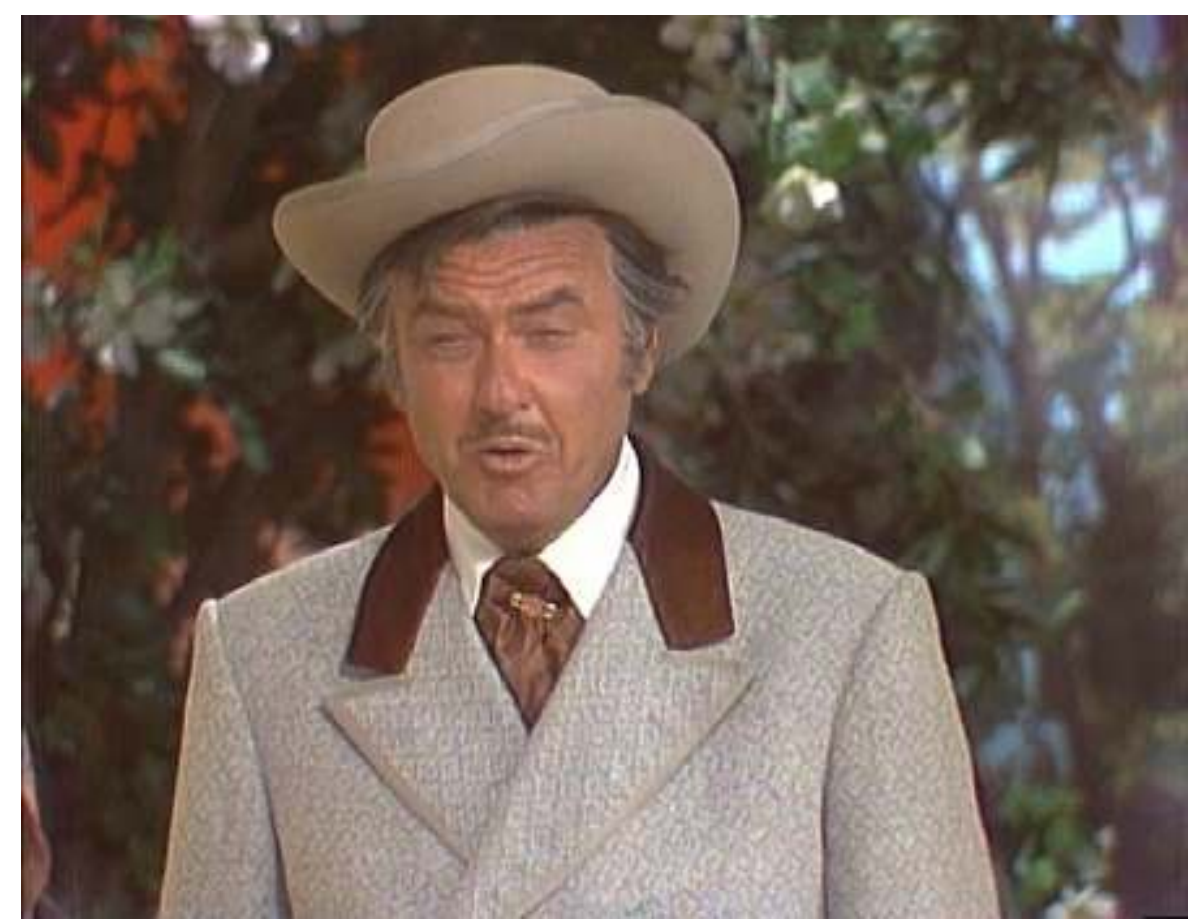

The rat-like, never perfectly gentlemanly Ratt Butler (Harvey Korman). (Went With the Wind 11:32)

13 Try as it may, American popular culture has proved unwilling and unable to untie itself from the knotty, tricky logic of classically constructed Southern melodramas. When observing the shifts, reversals, and cross-readings which in turn accelerate, slow down and disrupt the melodramatic flow, the typical "Old South" storyline, settings, figures, tropes, and staple characters seem to persevere as a palimpsestic background spectacle, leaving us pondering over the driving forces beneath these parodic sequels and other remakes yet to come. A number of questions are raised by what simply refuses to go away with more modern trends and winds, to keep returning obsessively through books, scripts, songs and scenarios. Not merely in the form of rehabilitated character types, restaged stock scenes, reworded catchphrases, but through the elaboration of increasingly extensive "counter-texts."

Unquestionably, as confirmed by Hutcheon and Harries, parody is a more complicated, more ubiquitous, ${ }^{9}$ as well as a less polarized notion than one might think. After recalling that owing to the presence of the prefix "para-" which "creates the connotation of 'counter' or 'against," parody has traditionally been defined as a "derivative of the Greek term paroidia, a burlesque or "counter-song," Harries adds that, as a "counter-text," parody has often been viewed as a "mode that essentially ridicules another text by mimicking and mocking it" (Harries 5). On the other hand, Hutcheon has claimed that along with "parody's counterness," the prefix "para-" may also be understood as "besides," in reference to what may exist or operate "alongside" (Harries 5). Accordingly, efforts to both at once deride and cross-examine the nostalgic cultural construction called the "Old South" characterize the humorously hysterical reenactments of Gone With the Wind targeted by The Carol Burnett Show.

While mocking the melodramatic imagination by alternately overstating and belittling its emotional gesturing, sensational stage effects and implausible plot shifts, what Harries in Film Parody calls a "prototext," reveal their plasticity. Indeed, as static as 
Mitchell's novelistic subtext may seem, it succumbed to the TV show's manipulative handling without much opposition or resistance.

In the process, two feminine foils previously overshadowed by Scarlett O'HaraMelanie Wilkes and Prissy-gain a brand new autonomy in this version destined to the consumers of TV-mediated fiction, less interested in $19^{\text {th }}$-century social and literary constructions than in the way the classic story has been updated for $20^{\text {th }}$-century audiences. And since Burnett's sketch bears the clear imprint of the 1970s, it hardly comes as a surprise that the focus now frequently shifts from the (in turn) syrupy and fiery male-female relations to the issue of sisterhood:

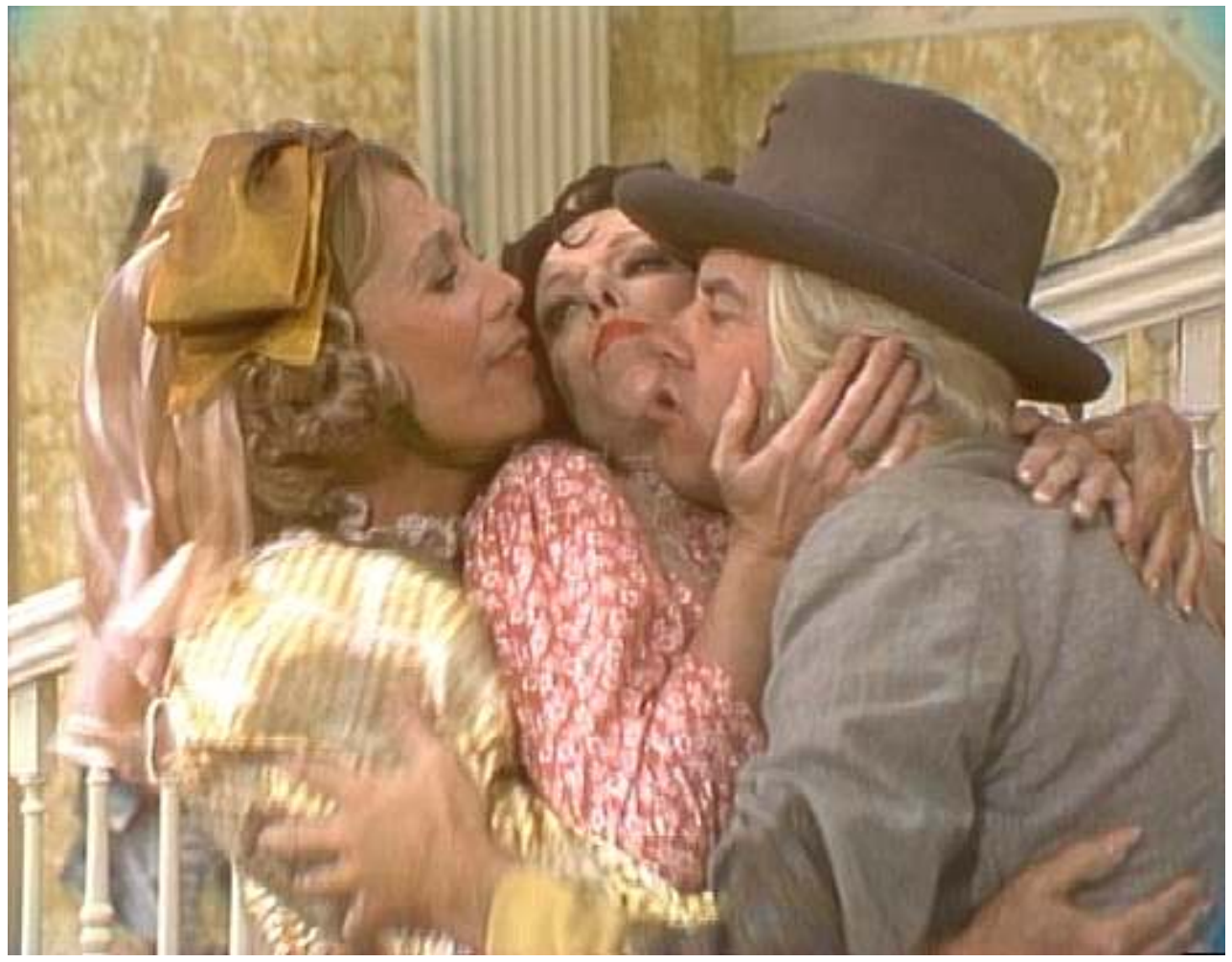

Challenging $19^{\text {th }}$-century sisterhood in the 1970s: Starlet sandwiched between Melody and Brashly. (Went With the Wind 08:50)

Melody: May I take this moment to tell you how very much I admire you, and I certainly hope someday we can be as close as sisters.

Starlet: In the meantime, Melody, why don't you just stick your head in the punch bowl. I'm sure it could use a little more sugar.

Melody: All right. [Melody plunges her head into the bowl.]

As this dialogue extract proves, Carol Burnett's neo-Scarlett-re-named "Starlet,"10 echoing the spoof's playful, self-reflexive mockery of the Hollywood star system-has not lost her capacity to upset the old customs of the country ruled in Gone With the Wind by a landed gentry. Nor has she lost her verbal vigor after her satirical transformation into a modern loudmouth of sorts. On the contrary, her criticism of the emblematic old World Melanie-the likewise lampooned and renamed Melody (Dinah Shore)-the perfect Southern Lady endowed with endless sweetness and patience, however horrid the war-time circumstances, grows even sharper when put into blunt, contemporary language. After the bra-burning $60 \mathrm{~s}$, this type of linguistic updating could only render more appealing Starlet's resistance to female submissiveness and passivity. 

add a little more sugar to the beverage and to lose some of her own sweetness-the sardonic advice is made less caustic by Melody's later use of different rhetoric. In a metafictional twist to the pre-existing novel, to create a further rupture from the background text, Melody informs the audience and the other characters on stage that she is about to die. Starting out her speech act by talking like a $19^{\text {th }}$-century plantation heroine and gesturing like Griffith's silent-era stars, Melody announces her imminent death with formal clichés and already dead metaphors: "Please, pardon the intrusion. I do hate to be a bother, but I do believe I'm going to that great plantation in the sky." Then, as if the effort of uttering these words had depleted the sweet little lady of all the energy she had left, Melody slumps down in the middle of the stairs.

The tongue-in-cheek sketch gains interest when Melody sends Starlet a more personal, pre-mortal message. Having thought of their friendship, Melody now wants to tell how she "really felt." As Starlet is listening to "Melly" without a clue to what she has in mind, Melody suddenly gives the mistress of Terra so brutal a push that the latter lady tumbles down the stairs of the central staircase-always far more than a simple part of the set in the classically told Southern melodrama. Melody's ${ }^{11}$ presence in this abridged, goofy reinterpretation ends with her elated, "Now, I can die a happy woman." After her joyous "Bye, y'all!" in the Southern drawl, Melody blows an ultimate Hollywood kiss and then simply drops dead.

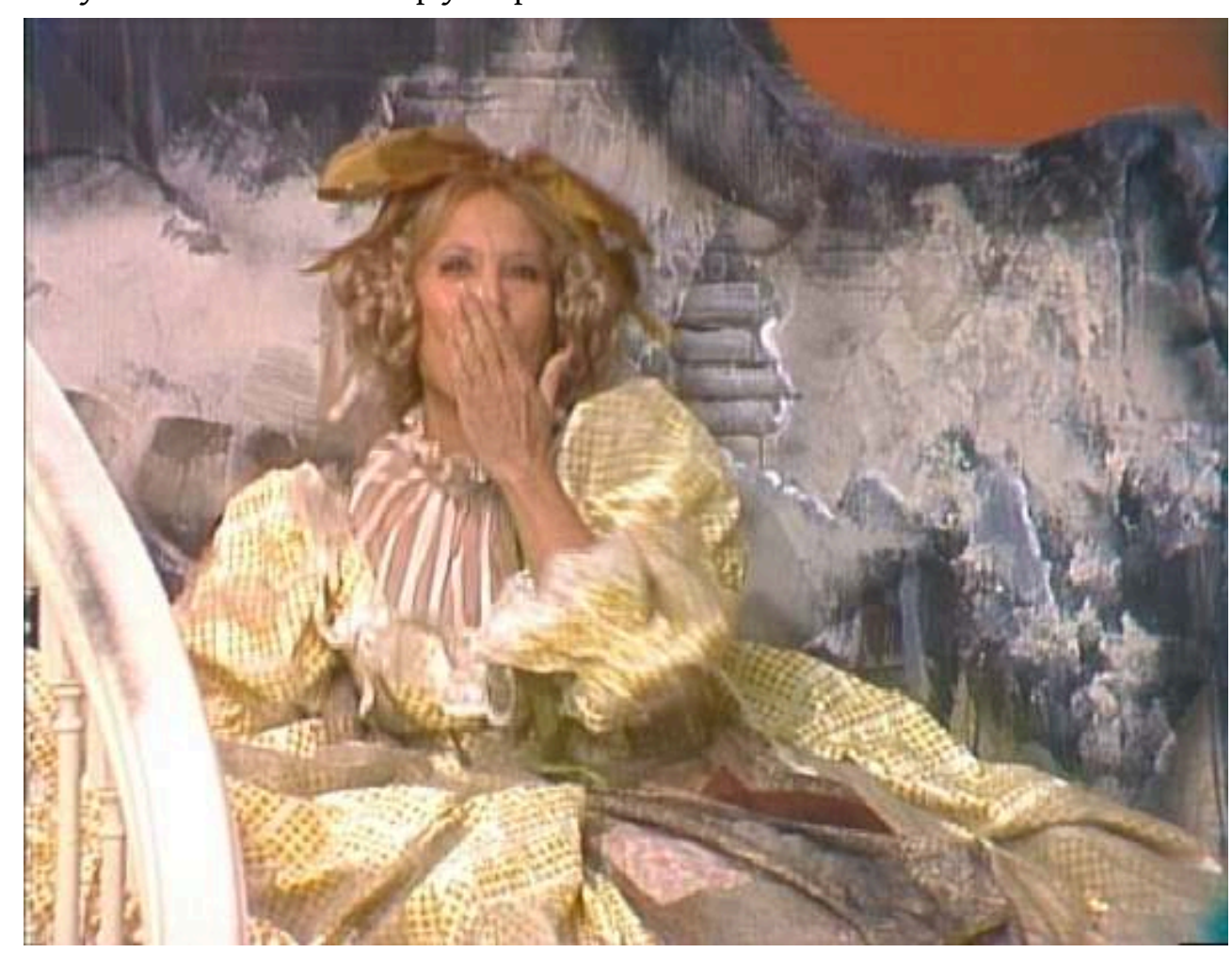

Melody: "Now I can die a happy woman!" (Went With the Wind 17:20)

However foreseeable, the demise of the long-cherished Southern angel-woman-finally "gone" to the "great plantation in the sky"-provokes a great commotion among the other recast characters of The Carol Burnett Show. The most panicky of them all is, of course, Brashly (Tom Conway), the Southern Lady's male counterpart. 
Contradicting the archetypal Southern gentleman, the comedy-variety show's Brashly turns out to be far less "ashen" than the Technicolor film's pale and pallid Ashley Wilkes, embodied by the British actor Lesley Howard who simply hated the role. As hinted by Ashley's new name, the rechristened character is to energize and, once again, modernize the moribund, always somewhat ashy old World aristocrats. And sure enough, although classic stereo-typing was, to some extent, already challenged in Mitchell's text, what we discover here is somebody far more "rash" and "hasty"literally too dynamic to be equated with the Hollywood-produced Ashley.

This is made evident by the accelerated sequence that follows Melody's death where Brashly is seen rushing up the stairs to exclaim, next to Melody's lifeless body: "Wait a minute! Hold it! Wait a minute! You can't go! You can't go! Wait a minute!" As a preposterous, fast-track "counter-song," parody here works both "against" and "alongside" the literary and filmic subtexts, at once mocking, criticizing and paying an ambivalent homage to the evergreen and ever-present background text.

This is confirmed by the subsequent double entendres where slight shifts in accent emphases do succeed in introducing a few new nuances into the otherwise repetitive dialogue, creating what Harries calls "'slides' in the syntax" (Harries 47):

Brashly: She's gone! She's gone! She's gone! Look at her! She's gone! She's gone! Gone, gone, gone! She's gone! Gone! She's gone!

Starlet: Wha..., Brashly, you... you really do love Melly?

Ratt: You never let yourself believe that, could you, Starlet?

Starlet: Wha..., no..., I know he really did love her, but I never knew he really, really, really, really, really, really did love her.

Brashly: "I really, really, really, really, really did love her, and now she's gone, gone, gone. She's gone. I really, really did love her and now she's gone, she's gone. She's gone.

I really did love her. She's gone. And I'm gone.

Overcome by loss, it is now Brashly's time to leave the scene. But not before his tongue has got virtually stuck with the past participle of the verb "go," till his increasingly unintelligible litany of mumbled "gones" ends with a final "And I'm gone." Until then, it is as if the abbreviated, still recognizable "gone"-driven title of the renowned novel and film had spread through the dialogue like a virus, contaminating and defamiliarizing the eminent prototexts. When counterbalanced by the more hesitant adverb "really," the more affirmative "gone" raises further questions concerning aesthetic and ideological reiteration in film and TV scenarios. Together with its other lexical and narrative rearrangements, Went With the Wind thus suggests that, regardless of its finalsounding title, what had so pompously "gone with the wind" may very well return, even in ironically stylized and parodically twisted lexical forms.

As Taïna Tuhkunen (2017) has argued, it seems that in the absence of a critical category called "the Southern"-a complementary more than a perfectly oppositional group of films which interacts with established generic categories, such as the Western-what we have here is a heterogeneous, still-to-be-named, always somewhat illicit canon that keeps rewriting itself-in this case, through parody-within an oddly elastic, porous and active "inter-genre." Whatever ultimate term one may wish to apply to the Southinspired film scenarios and TV texts, beyond their obvious emulation, these films have also proved capable of generating creative irony and critical havoc in the blissful and nostalgic master narrative proposed by D.W. Griffith in The Birth of a Nation (1915), which, like Gone with the Wind a quarter of a century later, deliberately mis-understood 
and mis-handled a number of myths and legends brought into the New World by European immigrants. ${ }^{12}$

Although less prominent until the end of the $20^{\text {th }}$ century, parodic versions of the "Grand Old South" have existed since Buster Keaton's vaudevillian cinematography and ironical acting in The General. As early as 1926, Keaton's chivalric poses and old-world gallantry poked fun at the imported knights and post-medieval Victorian damsels in distress-figures which had been reworked into over-sentimentalized $19^{\text {th }}$-century plantation fiction that was to impact filmic stories about the American South.

As we shall see, despite its apparent lack of racial awareness, the code-conscious Carol Burnett Show sets up, just as self-consciously, the Southern Scarlet woman as a red herring whose typical role was to distract the attention away from the realities of the "peculiar institution," refusing to even pronounce the word "slavery."

\section{Killing the Southern "Angel in the Mansion" Through Parody}

Ratt: My wish won't come true, Sissy. It, like my dreams, have went with the wind. Sissy: What wind?

Due to The Carol Burnett Show's aesthetics of distortion, even the perfect, self-sacrificing wife and mother exemplified by Melanie Wilkes gets a fleeting new life by breaking elatedly away from the grips of the mute yet no less powerful idol of domesticity. The moment of fame in the life of the humorous, transatlantic replica of the $19^{\text {th }}$-century Victorian angel-woman may be brief; what matters is the intertextual connections Burnett's parody feeds upon.

Unlike the woman speaker who in Virginia Woolf's essay "Professions for women" announces that had she not killed the "angel in the house," ${ }^{13}$ she would have been killed by the controlling, paralyzing (ideological) idol, Burnett's fiery parody, quite audibly, "burns it." By means of reorganized stage directions, rearranged costumes, reshuffled and hybridized characters, as well as contagious punning, Burnett's parodic action tackles the historically and culturally embedded representations of ideal femininity entertainingly and humorously in order to fight the cultural and political construction of "feminine mystique" 14 with laughter. As Susan Horowitz has observed:

[a]s a comedienne, Burnett has tremendous energy, physicality, and a willingness to take "unladylike" risks. Swinging doors dump her into potted palms. Leg casts trip her onto trays of cocktails. Giraffe-limbed and rubber-faced, she lampoons Gloria Swanson in Sunset Boulevard as a screaming harridan. She tosses back a hyperfluffed wig as Farrah Fawcett and coughs her way through Ali McGraw's death scene in Love Story like a commercial for Vicks Vaporub. As "Starlet O'Hara," she descends the staircase of a burned-out southern mansion in a dress she has whipped up out of old velvet curtains-complete with curtain rods which poke her shoulders out into line-backer proportions." (Horowitz 74)

In keeping with Burnett's carnivalesque logic, Went With the Wind proposes a dialogic, showy network where incongruous elements clash, and nonetheless tie the knot. As already seen, owing to the show's telling anachronisms, the cultural creation called the "Southern Belle"-regarded more and more like a bubble brain since the 1960ssuddenly comes to her more modern senses, as the authors of the episode, Hawkins and Sage, render Melanie self-reflective and empowered enough to evacuate her own character from the classic story. Not because of her waning health, but because she 
thus decides. One can, of course, consider this hasty exit from Went With the Wind's storyboard as a minor detail, but in its minute way, Melody's burlesque death reflects the more far-reaching, often quite radical winds that started blowing through American popular culture in the 1960 s.

Despite its avoidance of race issues, the main interest of the Went With the Wind episode resides in its parodic restaging of the clichéd white Southern aristocracy at the heart of the "re-mastered" Gone With the Wind narrative. Rather than struggling to defeat the over-romanticized, nostalgia-laden tale of a segregationist, chauvinist, racist and sexist "land" with the help of branching-out story-lines, ${ }^{15}$ Burnett's sketch picks up the déjà-lu sentimental plot, choosing an artillery of a different kind to try and break through the amazingly solid, sugar-coated surfaces of the classically constructed, movie-made American South.

The weaponry used is called, simply enough, "exaggeration." Although the Burnettian criticism of the "Old World" codes could, of course, be arranged into more detailed divisions (irony, parody, satire, caricature, wit, etc.), what counts is the capacity of the re-mise-en-scene to remain in dialogic contact with the "background text" by intensifying and amplifying many of the features already present in the classic movie. And whatever the targeted "lexical, syntactic, and stylistic elements of the prototext," as Harries says, exaggeration "extend[s] them beyond their conventionally expected limits" (Harries 83).

This is the case with the dramatic overkill of Melanie in Went With the Wind, which adds a further form of exaggeration to the tissue of overstatements, overemphases and overacted sequences of The Carol Burnett Show. The comedy looks beyond foolishly behaving women and men into Hollywood-promoted typologies and typecasting, as it keeps poking fun at the polarized visions of the South, even after the falling into ruins of the old, patriarchal South.
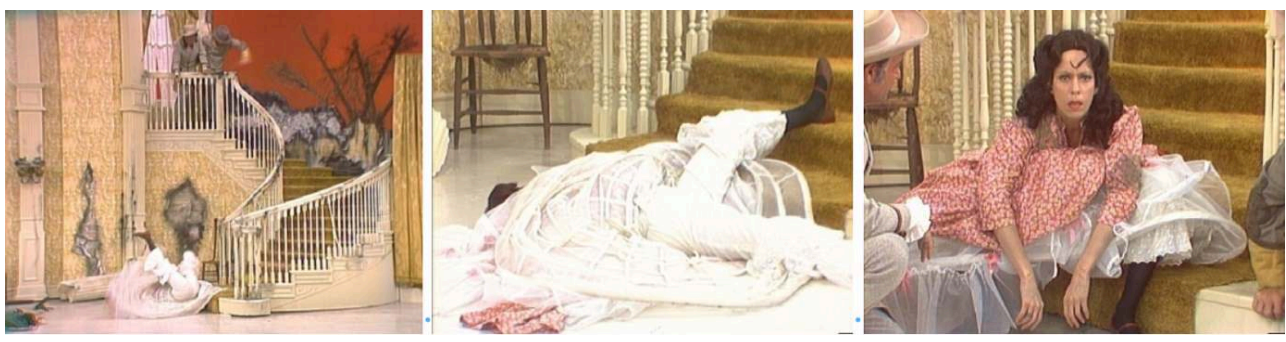

A visual sample of Carol Burnett's rough-and-tumble performances. (Went With the Wind 15:44-17:12)

On the one hand, there is the "Melanie Wilkes-type," too virtuous to survive the postbellum brutality, especially when pitted against the transgressive dramatis personae of the "Scarlett O'Hara-type." Although the motor of the narrative, the latter type was to be punished for her outspokenness, enterprising spirit, or mere physical energy before the movie was over. We could add, that in films of the Hollywood Code era (officially abandoned in 1968, a decade before Went With the Wind)-when the American movie industry was still policing itself to produce films considered as "moral" and in accord with "correct thinking"-it was the "Scarlett type" of female characters who required punishment for their transgressive infractions, especially in classic Southerns, as well as in classic noir films.

It would be difficult to ignore how Burnett's melodramatically gesticulating, theatrically over-acting, eye-rolling and wildly vocal Starlet O'Hara mimics and mocks 
this very logic of sexual segregation-already targeted, with more subtle mockery in Margaret Mitchell's novel. Burnett takes the constructedness of these generic categories even further; she tackles deep-rooted stereotypes in classic and contemporary language to concoct an even more hybrid version of the pre-Second World War "new woman," presented by Mitchell as a culturally cross-bred, neo-rural "flapper" straddling between the $19^{\text {th }}$ and the $20^{\text {th }}$ centuries. And as Burnett reconstructs the unbearably light and white plantation "Lady of the South"-already influenced by Sir Walter Scott's historical novels and reimagined medieval ladies-this central cultural icon of pre-Civil War plantation literature is rushed into the limelight with her recognizably Hollywoodian mannerisms. Operating thus both "against" and "besides" recognizable types, Went With the Wind no longer left the spectators shedding tears. Instead, the vigor and gusto of Burnett's playful, pathos-rejecting recreation of the déjà vu weepy made the TV audience cry out of laughter.

Let us, however, be clear about one thing: the subversive 1976 tearjerker is not a technical masterpiece, far from it. No use trying to compare the meticulously elaborated color, sound and camera techniques of David Selznick's superproduction with the speedily assembled TV sketch whose very essence lies, at least partly, on improvisation and literal sketchiness. That said, it is precisely the lack of refinement in the rough, iconoclastic treatment of the pre-existing oeuvre that often triggers laughter.

From the opening sequence on, the underlying emphasis of Went With the Wind remains on the always somewhat enigmatic "loss," crucial when trying to understand the enduring fascination of the "Old South," and so eagerly reconstructed through the early decades of American cinema. Once set up next to the mythic, long-gone "land of Cavaliers and Cotton Fields called the Old South," unfolded by the magnificent opening credits of producer David Selznick's ${ }^{16}$ Gone with the Wind, the more ordinary-sounding Went With the Wind challenges this on-going filmic reconstruction game by using ostensibly simple means.

One of them is the repeatedly emphasized absence, lack, or loss, highlighted by the (missing) noun beneath the title phrase "going with the wind."-For, what or who is it, one might ask, that has so melo/dramatically, magnificently and pompously "gone" or vanished "with the wind"? To disappear, along with the passing wind, to wherever the winds tend to go. This is a question that seeks an answer beyond Vivien Leigh's powerful final monologue, interspersed with the voices of other characters of the film to which Went With the Wind seems to provide a few amusing answers.

The same ongoing word game or gap-filling activity characterizes the TV show's dialogue-for instance, when Brashly tells Starlet that his money (which could have helped her pay her Yankee-imposed taxes) somehow simply "went with the wind." When the puzzled Starlet exclaims "Wind? What wind?", a likewise exasperating yet stimulating instance occurs when Ratt Butler says to Starlet's enslaved servant, Sissy (Vicky Lawrence), that he doubts his wish will ever come true, adding: "It, like my dreams, have went with the wind." This time it is Sissy's turn to ask: "What wind?"

Playing with our knowledge of the well-known story, but also with our command of English grammar, The Carol Burnett Show's shift from the present perfect ("gone") to the simple past ("went") - considered as the only true past tense in the English languageseems to set up the two "Souths" within two separate yet overlapping temporalities. While the "past tense-South" or the "preterit ${ }^{17}$-South" seems to evoke something more 
definite or final-a time-bound topos, like the South of the Civil War, which took place or lasted between 1861 and 1865-the "present perfect-South" refuses to be plunged into the past, insisting on the associations between the past and the present.
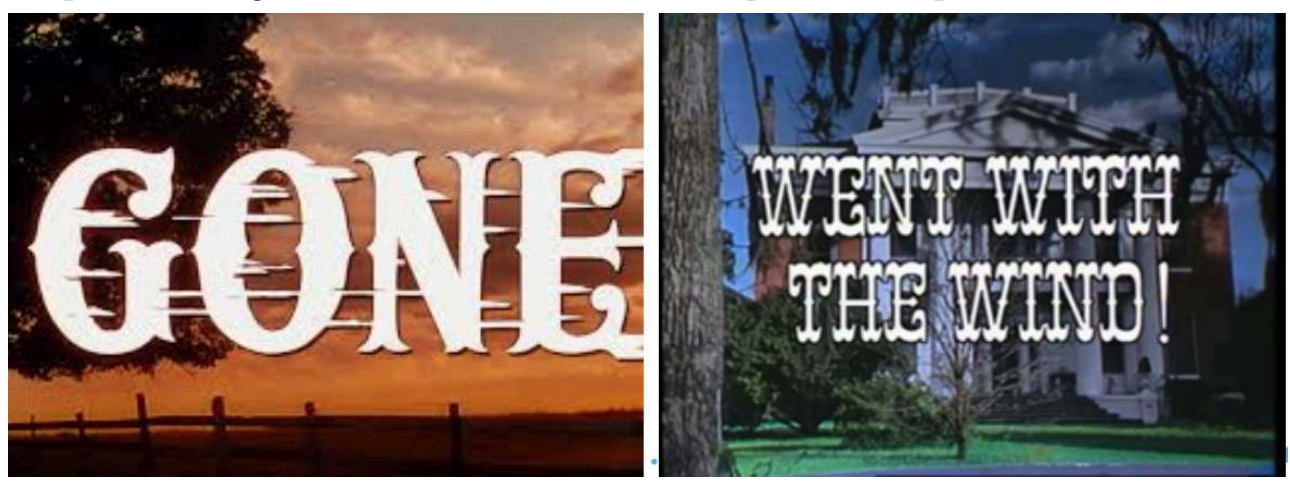

"Gone" or "Went": that is the cinematic and grammatical question! (Went With the Wind 00:00)

It is this latter, picture-perfect South, which has kept compulsively coming back to exhilarate, haunt and puzzle the consumers and commentators of American popular culture, that Burnett's 1976 parody invites us to reread in a different light. And in order to appreciate, even more widely, its comedic decoy messages that lure us into the deeper layers of this seemingly superficial show, we should not forget what Harries calls parody's "bitextual structure," its "refusal of semantic univocality" and of "structural unitextuality." (Harries 30)

\section{Taking Comedy Seriously, or How Scarlett Tumbles off the Pedestal}

Rather than unfolding, storybook-like, on fairy-talish impressions-with Mitchell's words and sentences that move across the movie screen in homage to the popular novel and its bygone world of earthly bliss-the opening words of the TV show offer us a far more trivial and duplicitous tribute. In place of the box-office film's title which is literally "going," moving from the right to the left, suggesting a return to the past, the title of Burnett's sketch sticks stubbornly to the middle of the screen, as a reminder of the fundamental fixity of the about-to-be-retold story.

This is one of the first major alterations among later shifts and inversions that reenergize the already-seen Gone With the Wind, owing to the TV show's knowing absentmindedness regarding the legendary substory. Familiarized by the TV-sketch format, and boosted by gags and intertextual puns that keep bouncing back and forth within the misread system of references, the iconic Belle is downgraded from the status of a mythic and melodramatic "Lady" into a more commonplace, contemporary character.

Together with its economic format, the (new) target text attracts with its deliberately non-antebellum discourtesy, its less refined, more uncivil "cut the crap" approach to classic melodrama. During the sketchy and parodic replay of the pathos and paraphernalia inspired by the proto-drama, the lengthy home-front Civil War film is turned into a comedy of errors where engagements, marriages, wars, conflicts, childbirths, fires and deaths are joyfully crammed into a barely quarter of an hour-long show played in an accelerated mode, like a fast-paced silent era movie. 

Atlanta and set the state capital of Georgia aflame. Like the other "background texts," History is warped by the "foreground story" when, "One War Later," as indicated by the title card (17:12), a Yankee soldier (Lyle Waggoner) knocks at the door to ask for a match to light up the city of Atlanta.

Yank soldier: Ma'am, this is to inform you that General Sherman's army is now occupying Atlanta. You got a match?

Sissy: Oh, yeah, sure. Here you go.

Yankee soldier: Thank you.

Starlet: Sissy? Who was that at the door?

Sissy: Just some soldier.

[Starlet looks out of the window.]

Starlet: Great balls of fire! They're burning Atlanta! 
Similarly suggestive are the repeated references to two early cinema genres: melodrama and the more vulgar slapstick comedy-both of which rely on narrative excess. Without grasping how these two genres clash and interact through this essentially "bitextual" and "bigeneric" TV parody, it may be difficult to find humor in some of the scenes where Starlet keeps pratfalling, tossing things, and slapping Sissy's face. As we know, this type of on-stage knockabout violence can be traced back to $16^{\text {th }}$ century Renaissance comedy. In a comparable manner, the 1970s' American TV show involves a pack of stock characters to set them up in ludicrous situations. And, like the commedia dell'arte's ubiquitous, easily recognizable Harlequin character, Scarlett is identified because of her flamboyant mannerisms and colorful gestures, words and costumes, many of which remain open to seemingly endless variations.

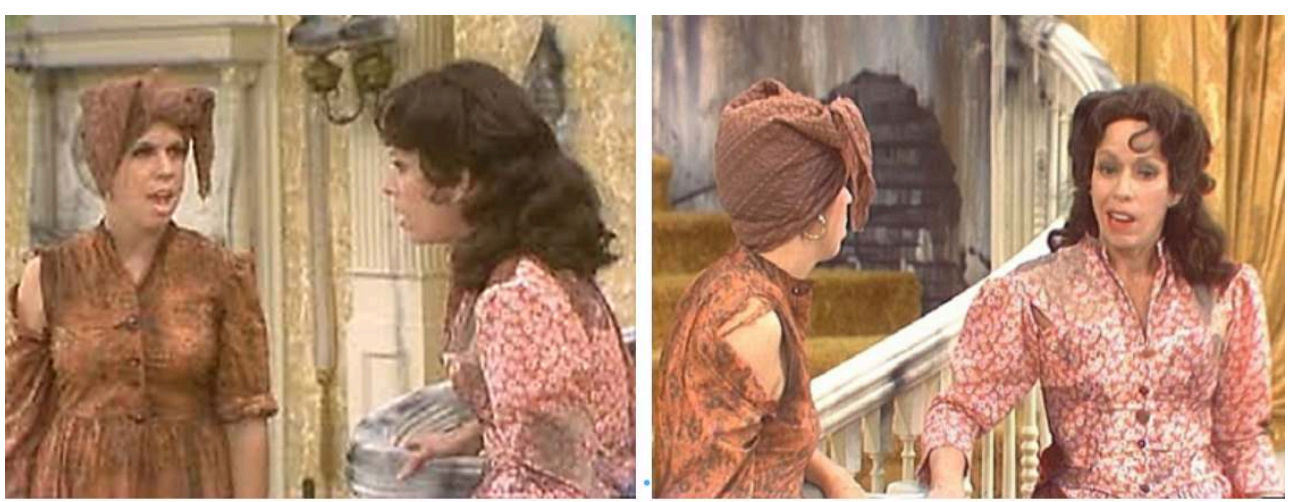

There is method in parody: Sissy (Vicky Lawrence) and Starlet (Carol Burnett) in the postbellum, postfeminist Civil War drama. (Went With the Wind 10:02; 12:50)

One such instance coincides with Starlet's knowingly heartbreaking repetition of "What'll I do? What'll I do?"-a question that resonates with countless stock scenes where a helpless damsel is desperately waiting for a male hero to come and free her from the current predicament. Something has changed, however, because the (feminine) plea for (male) help is, here, picked up by the sassy Sissy who discards agitation, never falling into oversentimentality. Instead of whining, Sissy gives herself a slap and blurts out: "I'll think of something!" This is but one example of Carol Burnett's will to impersonate, all through her weekly, 11-year long show, a variety of female characters with agency in parodies of the kind that "scavenge worn-out conventions and their accompanying over-predictability" (Harries 123).

51 The introduction of slapstick into the paradigmatic, strictly gendered "Old South" moves Burnett away from melodrama, beyond graphic violence and mere misogyny, in the direction of post-modern plays with cultural codes and categories. And by means of uninhibited action and generic overlapping, the slapstick-heavy TV-show ultimately breaks into melodramatic patterns, to interrogate the place of women among great male entertainers, such as Charles Chaplin, Buster Keaton and Harold Lloyd. Only during the later decades of the $20^{\text {th }}$ century did female comedians gain wider recognition and expose, in their self-consciously "female" ways, the question of gender and laughter-almost one century after Louis Lumière introduced slapstick to the cinema in The Waterer Watered (L'arroseur arosé, 1895). ${ }^{19} \mathrm{Just}$ as blatantly as the TV show flirts with melodrama, The Carol Burnett Show toys with silent-era slapstick, as highlighted by the self-reflective slapping scenes-Sissy's self-slapping, but also by the way slapping as dramatic action is eventually turned against the classic white slapper, 
Scarlett. Just like Louis Lumière's "waterer" ("arroseur"), Starlet, too, gets "soaked" ("arrosée"), i.e. "slapped" in the end.

Further interfilmic thrills created by the Burnett parody lie in the fact that we always know more about the plot than the characters. Owing to dramatic irony, we are constantly invited to speculate on how the displaced stock characters might act, talk and move during a given scene. In the same vein, we are led to reflect on the dead (or dying) metaphors, brought back from wherever they had "gone" since 1939. Through all these "losses" which, in a sense, counterbalance the magnified "Lost Cause" ideology, we participate in the filling in the blanks created by the parody's deliberately faulty memory; we are invited to try and complete the bigger picture based on the always larger and elusive metanarrative about the American South, whose cultural work was already under way before Griffith's Birth of a Nation and the first film adaptations of Harriet Beecher Stowe's Uncle Tom's Cabin. ${ }^{20}$

The slapstick sequences tackle the melodramatic iconography, but to dismantle Mitchell's gallant fantasy world of knights, fair ladies, and happy slaves, the hackneyed plotline required not a mere bow and a slap, but quite a few narrative blows to shake up the story out of its preposterous logic of false harmony.

The most memorable Gone With the Wind-inspired scene of Went With the Wind begins as Starlet is getting ready to use her (explicitly "female") wits to trick Ratt into giving her the cash she needs to pay her taxes to keep Terra. There is, however, a slight problem. Like the décor of her mansion, her raggedly clad body is not sexy enough to be seen by a man. After Sissy tells Starlet to "hide behind the drapes" not to appear in rags, Starlet grabs the green velvet curtains and rushes upstairs. A little later, she reappears at the top of the stairs, but rather than wearing Vivien Leigh's déjà-vu draperies made out of the Tara curtains, Carol Burnett's accoutrement includes the prominent, metallic curtain rod that went with the curtain.
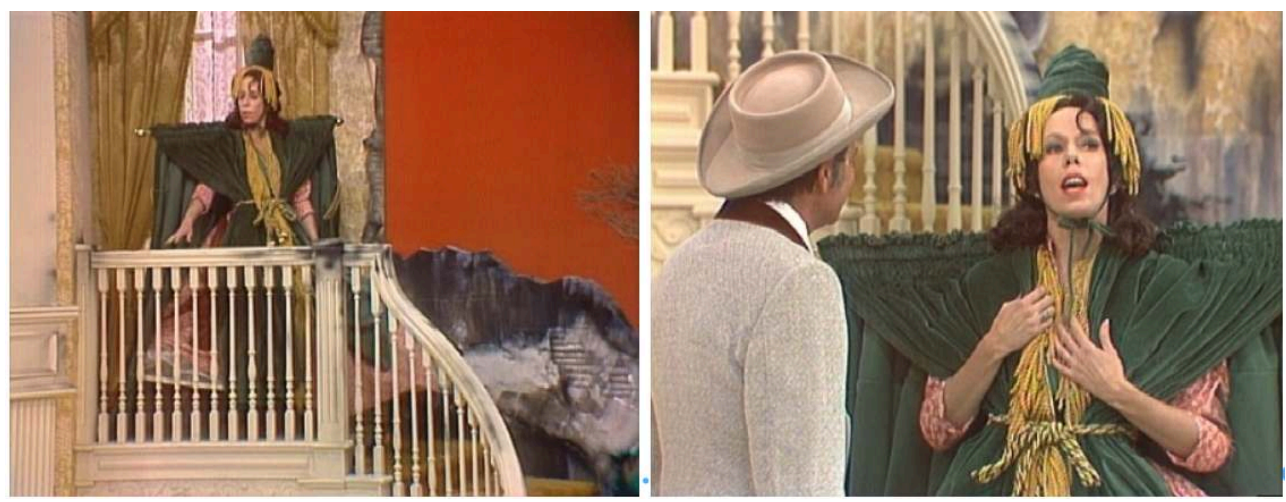

Ratt: "That, that, that gown is gorgeous."

Starlet: "Thank you. I saw it in the window, and I just couldn't resist it."

(Went With the Wind 13:03; 13:34)

Hugely outspreading her shoulders, the rod gives Burnett's Scarlett a powerful new look, and after strolling down the stairs-enjoying every second of her showy descentshe asks the adoringly gazing, only faintly Clark Gableish Ratt Butler: "What, uh, what brings you to Terra?" Mesmerized, Ratt stumbles over his words when trying to find the right expression: "You, vixen, you. Starlet, I love you. That, that, that gown is gorgeous." While the TV audience was already roaring with laughter, it laughed even harder when hearing what Starlet had to answer: "Thank you. I saw it in the window, and I just couldn't resist it." 
Obviously enough, Starlet's broad-shouldered, hilariously Herculean look endowed the "Southern Lady" with instant agency and a touch of queer energy. It compressed into one single sight-gag (informed by the tradition of burlesque and slapstick), the immortal moment at the end of the first part of Gone With the Wind, when Scarlett appears to be carrying the weight of the entire South on her shoulders, trying to lead the motley crew composed of her remaining family and friends, and a grim cluster of ex-Confederate soldiers, all living on the now-ruined O'Hara plantation.

In Burnett's incongruous, highly reflexive TV show which keeps referring to its own artificiality and malleability, the iconic, increasingly shoulder-padded and body-built "Southern Lady" remains as pivotal as within the modus operandi of classic Southern melodramas. To the point that the above underlined contrasts between the "Melanietype" and the "Scarlett-type" end up turning into a duel between two generic film categories, involving the two emblematic female figures.

Went With the Wind's "dress scene" was number two in TV Guide's list of "The 50 Funniest Moments in Television," still in 1991. Today, the now-famous "curtain rod dress," designed by costume designer Bob Mackie, is on display in the Smithsonian National Museum of American History, and its popularity was also confirmed by the launch of a commemorative Barbie doll representing Carol Burnett clad in the green velvet dress. Including the rod, of course!

\section{Conclusion}

59 Strikingly, it is only towards the end of the brief yet dense hyperbolic performance that the character of Sissy, played by Vicky Lawrence, moves center stage in this show where colored characters seem to have been relegated into an invisible backstage.

It had taken nearly forty years to transform Gone With the Wind's unbearably humble and self-demeaning Prissy (Butterfly McQueen) into a more affirmative, albeit white Sissy. No longer made to speak in a shrill, ear-splitting voice, as the childishly behaving Prissy, Sissy had things to say. And despite her obvious "colorlessness," the new maid's outspokenness seemed to do more justice to the memory of the house slave played by Butterfly McQueen-the black actress who ended up so disgusted with the roles of brainless maids she was offered that she finally slammed the door to Hollywood, and stopped acting.

1 While it would be easy to argue that this is simply another illustration of "white washing"-in reference to the American entertainment industry's efforts to render colored characters more appealing in the eyes of the white (money-spending) masses by turning them "white"-the role and status of the housemaid remains complex; not only because Sissy is the only added or "imported" character, but because she-not an iconic character in the first place-keeps upsetting and moving the story away from the subtextual or former fixities. Notably by working the overly motherly Mammy (Hattie McDaniel) and the exceedingly silly Prissy into a single yet hybrid, frankly-speaking white maid.

Without forgetting how Burnett challenges the enduring Master- and Belle-driven narratives, when attuned to the emerging white feminist movement, the TV sketch can hardly be read as an example of active oblivion of racist History; nor as a failed attempt to break away from what Kimberley Wallace-Sanders would later call the 
"Mammification of the nation" in Mammy: A Century of Race, Gender, and Southern Memory, an essay that draws attention to how the "mammy" figure both prolongs and contests the "romanticized mythology of the plantation as a utopia" (Wallace-Sanders 4).

On a more symbolic level, when approached through an intersectional angle, Starlet's repeated tumbling down the stairs connects with the contemporary claims to "take down" and/or contextualize Gone With the Wind. While we can only ponder over the consequences of the slapping of the 1930's blockbuster with recently added "content warnings" against outdated, intolerable attitudes, it is worth bearing in mind that despite its use of stereotypes, The Caroll Burnett Show already called for more equal power relationships. Rather than proposing yet another bow to the romanticized "Old South," her show shifted the emphasis on the movie-created South, when, after being slapped several times, it was the "stupid and silly" maid who took the upper hand by slapping the de-pedestaled and abusive mistress of Terra on the cheek.

Consequently, it is logical that in the TV version's ultimate inversion, it is not Scarlett/ Starlet who has the final word, but the servant who steals the final punchline from Gone With the Wind's male hero:

Starlet: Oh, Sissy! Sissy, what am I gonna do? What if I don't have Ratt? What am I gonna do? What am I gonna do? What am I gonna...?

[Sissy slaps Starlet.]

Starlet: Oh!

Sissy: Frankly, Miss Starlet, I don't give a damn.

We are not told if Sissy, the "new woman" of the 1970s, abandoned, Rhett Butler-like, the Terra plantation at the end, or if she started a feminist awareness group with the former plantation mistress. One thing seems certain, however. Sissy doesn't "give a damn" about the typecasting practiced by classic melodramas and worn-out "women's weepies."

However mixed one's feelings may be regarding the racist traces, and the more or less subversive or parodic follow-ups of Gone With the Wind, the text-, cinema-, and TVmediated tenacity of the story proves that American popular culture has never completely fallen out of love with Scarlett O'Hara. Nor has it accepted the idea that "bygones are bygones." As Harvey Korman's Ratt Butler-the thus-renamed and parodied, never perfectly gentlemanly, actually quite a rat-like blockade runner-puts it in Went With the Wind when talking to Starlet's maid: “I'm a man of many wishes, Sissy. I wish this filthy war had never happened. I wish for a time when life was simple and beautiful. I wish I was in the land of cotton. Old times there are not forgotten." (Went With the Wind 12:15-12:29)

In the light of current debates, insidious forgetfulness no longer seems possible, as we are actively reminded of how the memory of the supposedly "great" Southern past has been perpetuated by euphemistic films such as Gone With the Wind. At the same time, as highlighted by Angelica Jade Bastién's article "What Are We to Do With Cinematic Monuments to the Confederacy?", other questions have emerged, although, as Bastién notes, "[g]iven its availability on any platform possible to watch a film, and its towering status, Gone With the Wind is under no threat of actual censorship, or of being wholly forgotten." (Bastién in Vulture, 2017)

67 Further discussion and research is certainly needed to help us establish more precise distinctions within the fierce debates currently surrounding Gone With the Wind, to 
improve our understanding of the links between the toppled Confederate monuments and the more slippery type of Confederate or cultural monuments Gone With the Wind is a good example of. For the time being, the author of this article cannot but share Bastién's doubts concerning any single message proposed by these films vs the statues set up in public places: "Whereas these monuments have one message-to celebrate and uphold a painful time in American history, whose scars linger to this day-a film, especially one with so many influences as Gone With the Wind, rarely holds a single message." (Bastién in Vulture, 2017)

This may also explain why it is the most amalgamated and "impure" character of The Carol Burnett Show who performs the TV show's last slap before the final clap. For, as underlined by the closing dialogue between Miz Starlet and Sissy, it is Sissy who seems to know what it was that ultimately "went with the wind."

Sissy: What did he say?

Starlet: He said, frankly my dear, I don't gi...

Sissy: Makes sense to me.

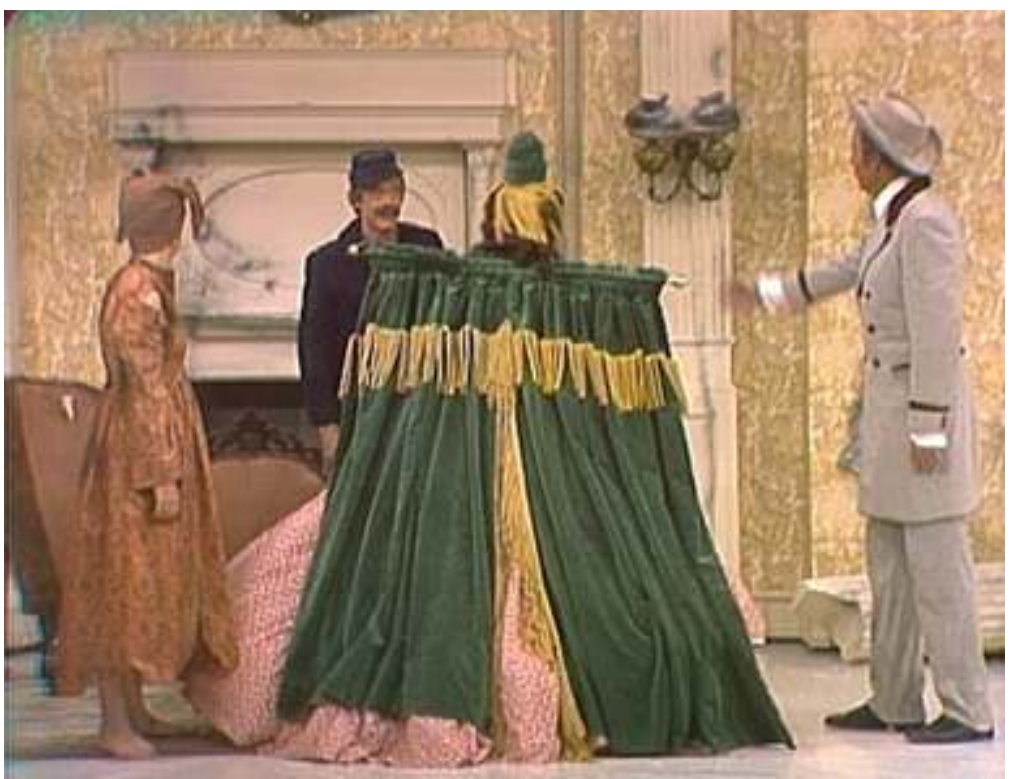

Starlet O'Hara's curtain rod dress, or the impossibility of a final curtain call. (Went With the Wind 14:06) 


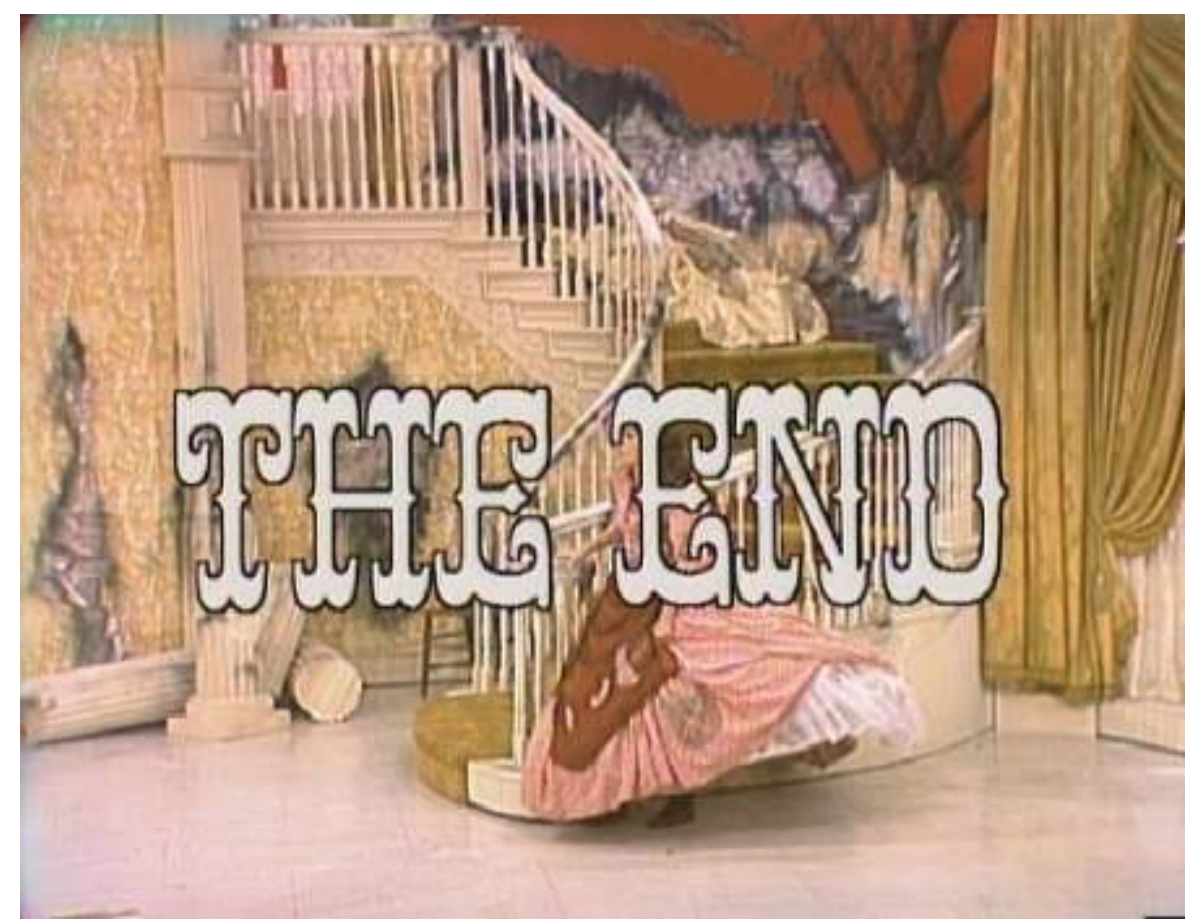

(Went With the Wind 19:00)

\section{BIBLIOGRAPHY}

BASTIEN, Angelica Jade. "What Are We to Do With Cinematic Monuments to the Confederacy?" Vulture. 10 June 2020. vulture.com/article/gone-with-the-wind-and-cinematic-monuments-tothe-confederacy.html. Accessed 4 July 2020.

BURNETT, Carol. In Such Good Company: Eleven Years of Laughter, Mayhem, and Fun in the Sandbox. New York: Crown Archetype, 2016.

DUTRIAUX, Claire, Anne-Marie PAQUET-DEYRIS, and Taïna TUHKUNEN, eds. When the West Meets the South on Screen / Quand l'Ouest rencontre le Sud à l'écran. La Revue LISA / LISA e-journal, vol. XVI, no. 1, 2018. journals.openedition.org/lisa/9180. DOI : doi.org/10.4000/lisa.9180. Accessed 25 June 2020.

FRIEDAN, Betty. The Feminine Mystique. 1963. New York: W. W. Norton, 1963.

GOMEZ-GALISTEO, Carmen. The Wind Is Never Gone: Sequels, Parodies and Rewritings of Gone with the Wind. Jefferson: McFarland \& Company, 2011.

HARRIES, Dan. Film Parody. London: British Film Institute, 2000.

HARRIS, Mark. "Gone with the Wind: The Absolutist Case for Problematic Pop Culture." Vulture. 10 June 2020. vulture.com/article/the-absolutist-case-for-gone-with-the-wind.html. Accessed 25 June 2020. 
HASKELL, Molly. From Reverence to Rape: The Treatment of Women in the Movies. 1974. Chicago: University of Chicago Press, 1987.

HOROWITZ, Susan. Queens of Comedy: Lucille Ball, Phyllis Diller, Carol Burnett, Joan Rivers, and the New Generation of Funny Women. Amsterdam: Gordon and Breach Publishers, 1997.

HUTCHEON, Linda. A Theory of Parody: The Teachings of Twentieth-Century Art Forms. New York: Methuen, 1985.

MERRIAM-WEBSTER. Merriam-Webster.com Dictionary. https://www.merriam-webster.com/ dictionary/preterit. Accessed 29 June 2020.

MITCHELL, Margaret. Gone with the Wind. New York, Macmillan, 1936.

MIZEJEWSKI, Linda and Victoria STURTEVANT, eds. Hysterical!: Women in American Comedy. Austin: University of Texas Press, 2017.

MULVEY, Laura. "Visual Pleasure and Narrative Cinema." Screen, vol. 16, no. 3, 1975, p. 6-18.

PATMORE, Coventry. “The Angel in the House.” The Betrothal. London: John W. Parker and Son, 1854.

RANDALL, Alice. The Wind Done Gone. Boston: Houghton Mifflin, 2001.

REGIS, Pamela. A Natural History of the Romance Novel. Philadelphia: University of Pennsylvania Press, 1991.

RIDLEY, John. “Op-Ed: Hey, HBO, 'Gone With the Wind' romanticizes the horrors of slavery. Take it off your platform for now.” Los Angeles Times. 8 June 2020. https://www.latimes.com/opinion/ story/2020-06-08/hbo-max-racism-gone-with-the-wind-movie. Accessed 25 June 2020.

ROBLIN, Isabelle. "From Parody to Rewriting: Margaret Mitchell's Gone With the Wind (1936) vs Alice Randall's The Wind Done Gone (2001).” Revue LISA/LISA e-journal [En ligne], vol. 2, no. 5 | 2004. journals.openedition.org/lisa/2911. DOI : doi.org/10.4000/lisa.2911. Accessed 25 June 2020.

ROSEN, Marjorie. Popcorn Venus: Women, Movies, \& the American Dream. New York: Coward, McCann \& Geoghegan, 1973.

SEIDEL, Kathryn Lee. The Southern Belle in the American Novel. Tampa: University of South Florida Press, 1985.

SPERB, Jason. Disney's Most Notorious Film: Race, Convergence, and the Hidden Histories of Song of the South. Austin: University of Texas Press, 2012.

STOWE, Harriet Beecher. Uncle Tom's Cabin, or Life Among the Lowly. Boston: John P. Jewett, 1852.

TUHKUNEN, Taïna. Demain sera un autre jour : le Sud et ses héroïnes à l'écran. Pertuis: Rouge Profond, 2012.

TUHKUNEN, Taïna. "Gone With the Categories, or the Knotty Naming of the Genre 'Southern”'. Film Journal, no. 4 | 2017, filmjournal.org/fj4-tuhkunen/. Accessed 25 June 2020.

WALLACE-SANDERS, Kimberley. Mammy: A Century of Race, Gender, and Southern Memory. Ann Arbor: University of Michigan Press, 2010.

WEST, Beverly and Nancy PESKE. Frankly, Scarlett, I Do Give a Damn!: A Parody: Classic Romances Retold. New York: Harper Collins, 1995.

WILLIAMS, Tennessee. A Streetcar Named Desire and Other Plays, 1947. London: Penguin Books, 1987.

Filmography 
The Birth of a Nation. Dir. D. W. Griffith. Written by Thomas Dixon Jr., D. W. Griffith, Frank E. Woods. With Henry B. Walthall (Ben Cameron), Lillian Gish (Elsie Stoneman), Mae Marsh (Flora Cameron), Ralph Lewis (Austin Stoneman), George Siegmann (Silas Lynch), Walter Long (Gus), David W. Griffith Corp., 1915.

The Carol Burnett Show (CBS, 1967-1978). Went with the Wind, Season 10, episode 8, aired November 13, 1976. Dir. Dave Powers. Written by Rick Hawkins and Liz Sage. With Carol Burnett (Starlet O’Hara), Harvey Korman (Ratt Butler), Vicky Lawrence (Sissy), Tim Conway (Brashly), Dinah Shore (Melody), Lyle Waggoner (Yankee soldier, Yankee minister).

The General. Dir. Clyde Bruckman, Buster Keaton. Written by Clyde Bruckman, Buster Keaton, Charles Henry Smith. With Buster Keaton (Johnnie Grey), Marion Mack (Annabelle Lee). United Artists Films, 1926.

Gone with the Wind. Dir. Victor Fleming. Written by Sidney Howard. With Vivien Leigh (Scarlett O'Hara), Clark Gable (Rhett Butler), Melanie Hamilton-Wilkes (Olivia de Havilland), Ashley Wilkes (Leslie Howard), Mammy (Hattie McDaniel), Prissy (Butterfly McQueen). Selznick International Pictures in association with Metro-Goldwyn-Mayer, 1939.

The Simpsons. Season 10, episode 223. Dir. Mark Kirkland. Written by Matt Groening, James L. Brooks, Sam Simon, Julie Thacker-Scully. With Tress MacNeille (Scarlett O'Hara's voice), Harry Shearer (Rhett Butler's voice), 2007.

A Streetcar Named Desire. Dir. Elia Kazan. Written by Tennessee Williams, Oscar Saul. With Vivien Leigh (Blanche Dubois), Marlon Brando (Stanley Kowalski), Kim Hunter (Stella Kowalski), Karl Malden (Mitch). Warner Bros. Pictures, 1950.

Uncle Tom's Cabin. Uncle Tom's Cabin \& American Culture, "Uncle Tom's Cabin on film" http://utc.iath.virginia.edu/onstage/films/fihp.html. Accessed 4 July, 2020.

The Waterer Watered (L'arroseur arosé). Dir. Louis Lumière. With François Clerc (the gardener), Benoit Duval (the boy), 1895.

\section{NOTES}

1. Written by two young screenwriters, Rick Hawkins and Liz Sage, the Went With the Wind episode 10.8 of The Carol Burnett Show was broadcast on CBS on November 13, 1976. At the end, in 1978, it counted a total of 11 seasons and 276 episodes. With its 25 Emmy Awards and 8 Golden Globes, the TV comedy remains one of the most popular shows in American TV history.

2. For a more thorough approach to this cultural icon, see Seidel (1985) or Tuhkunen (2012).

3. The premiere of Gone With the Wind on December 15, 1939 at the Loew's Grand Theater in Atlanta-preceded by a three-day celebration featuring parades, Confederate flags and a costume ball-was an all-white event, Georgia's Jim Crow laws banning the presence of the film's black actors and actresses, such as Hattie McDaniel, the first African-American actor to win an Oscar for her role as the O'Hara family's "Mammy."

4. A term used by Carol Burnett during her typical question-and-answer session with the studio audience when introducing Went With the Wind prior to the first airing of the episode in 1976: "Recently, nearly the entire nation spent a total of five hours watching Gone with the Wind make its TV debut. So for those of you who ran out of Kleenex, and were unable to watch it for the whole five hours, we've put together our own mini version to let you know what you missed!" (Burnett 115). 
5. Gone with the Wind has also been spoofed in TV series, such as The Sonny \& Cher Show (19761977), MAD-TV (1995-2009), French \& Saunders (1987-2007), and also, less surprisingly, in The Muppet Show (1976-1981).

6. The other classic romance tales retold by West and Peske where romantic heroes learn how to behave include Casablanca, The Great Gatsby and Romeo and Juliet.

7. This episode, which was originally aired on April 25, 1999, ends, ironically enough, with the following words: "Edited for seniors."

8. When theorizing parody, Linda Hutcheon establishes a distinction between "background" and "foreground" texts. According to Hutcheon, it is the superimposition of these two texts that counts when the newly generated, parodic text absorbs the pre-existing text/s and then "represents them within its own discourse, leaving some elements intact and reformulating others." (Harries 24)

9. "Parody is not a new phenomenon by any means, but its ubiquity in all the arts of this century has seemed to me to necessitate a reconsideration of both its nature and its function." (Hutcheon 1)

10. Etymologically "a small star," a promising young performer, or a young movie actress, coached and publicized for starring roles.

11. Melody's name recalls the extent to which classic Southern melodrama has, through its double-rooted etymology (melos/song and drama), presented the "Old South" also as a song; one of the most explicit and controversial ones being Walt Disney's Song of the South (Harve Foster, Wilfred Jackson, 1946). See Sperb.

12. To learn more about the "genre trouble" and other recreative disorders among dominant tropes and metanarratives provoked by "Southerns," see Dutriaux, Paquet-Deyris, and Tuhkunen.

13. See Coventry Patmore's poem "The Angel in the House" (1854). One of the most popular poems of the Victorian era, this long narrative poem celebrating married love as the finest and highest form of love between a man and a woman has been criticized for its syrupy sentimentality, as well as for the way it contributed to the cult of domesticity, reinforcing the Victorian rhetoric about a woman's "proper role" as a wife, a mother and a housekeeper.

14. In her famous 1963 essay, journalist and feminist activist Betty Friedan argued that postwar American society, blinded by the "feminine mystique" that perceived women as "happy housewife heroines," refused to see women as individuals. Friedan tackled the nameless misery many women were suffering from, helping thus to revive the dormant feminist movement, and in more general terms, contributing to the considerable social changes of the 1970s.

15. Of the kind elaborated, for instance, by Alice Randall in The Wind Done Gone (2001). See Roblin on "the subversive nature of the hypertext, which goes beyond simple parody."

16. Producer David Selznick's name appears in the opening credits, accompanied by the following, aggrandizing remark: "Selznick International in Association with Metro-Goldwyn Mayer has the Honor to Present its Technicolor production of Margaret Mitchell's Story of the old South."

17. "preterit is ultimately Latin in origin: it comes from praeter, meaning 'beyond, past, by.' (This meaning is also apparent in the now-archaic adjectival use of preterit to mean 'bygone' or 'former'.") "Preterit." Merriam-Webster.com Dictionary.

18. When Ratt appears for the first time in Went With the Wind (03:05), he introduces himself with the following words: "I'm Captain Ratt Butler. And I arrived here by way of a streetcar named desire," after which he immediately professes love for Scarlett.

19. A film about a household gardener who is watering a garden when a young man (a prankster) sneaks up behind him and steps on the hose. The puzzled gardener wonders what happened to the water flow, and when he peers down the nozzle, the prankster steps off the hose and the gardener gets sprayed in the face. The sequence ends with chasing and spanking. 
20. The novel was first published serially in 1851 in The National Era, a Washington D.C. abolitionist newspaper. For the numerous adaptations of the novel, see "Uncle Tom's Cabin on film."

\section{ABSTRACTS}

In the 1976 TV parody of Gone With the Wind (1939), Carol Burnett descends the grand staircase of a devastated Southern mansion in a green dress made out of antebellum curtains, complete with a rod that blows her shoulders out of proportion. Rather than downplaying the overromanticized Southern melodrama, the sketch proceeds through further exaggerations and distortions, seeking to shatter the cult text by spoofing, mocking, while paying a humorous homage to the evergreen background text. This essay argues that despite The Carol Burnett Show's dodging of race issues, the way it demystifies and takes down the cultural monument named "Scarlett O'Hara"-by mingling it with other generic conventions, such as slapstick comedysheds light on how Gone With the Wind can also work as a revelatory intertext. While failing to operate as a racial eye-opener, the 1976 skit paves the way for more critical reassessments of the famous cultural construction rooted in racist ideology and imagery.

Au cours de la parodie télévisuelle Went With the Wind (1976) de Gone With the Wind (1939), Carol Burnett descend l'escalier central d'un manoir sudiste dévasté, vêtue d'une robe verte confectionnée à partir de vieux rideaux et complétée par une tringle qui l'affuble d'épaules disproportionnées. Au lieu d'atténuer les débordements romantiques du mélodrame sudiste, le sketch procède par de nouvelles exacerbations et déformations, faisant voler en éclats le texte culte, en le parodiant et en le moquant, tout en lui rendant un hommage humoristique. Malgré le refus du Carol Burnett Show d'aborder les questions raciales, sa façon de démystifier le monument culturel nommé «Scarlett O'Hara ", descendu du piédestal au cours du Show, prouve que Gone With the Wind peut également fonctionner comme un intertexte révélateur-notamment en débordant sur d'autres conventions génériques, tels que le slapstick. Sans se focaliser sur les enjeux raciaux, le sketch de 1976 ouvre la voie à des réévaluations plus critiques de la célèbre construction culturelle enracinée dans une idéologie et une imagerie racistes.

\section{INDEX}

Keywords: Parody, adaptation, TV comedy, Carol Burnett, Gone With the Wind, Went with the Wind

Mots-clés: Parodie, adaptation, comédie télévisuelle, Carol Burnett, Autant en emporte le vent, Went With the Wind

\section{AUTHOR}

TAÏNA TUHKUNEN

Université d'Angers 